\title{
Vietnamese Students' Perceptions of Moral Values: An Assessment by Students at An Giang University
}

\author{
Chi Hai Nguyen \\ Department of National Defense Education, An Giang University, Vietnam National University, Ho Chi Minh City, Vietnam
}

Received August 14, 2021; Revised October 8, 2021; Accepted October 21, 2021

\section{Cite This Paper in the following Citation Styles}

(a): [1] Chi Hai Nguyen, "Vietnamese Students' Perceptions of Moral Values: An Assessment by Students at An Giang University," Universal Journal of Educational Research, Vol. 9, No. 11, pp. 1814 - 1825, 2021. DOI: 10.13189/ujer.2021.091102.

(b): Chi Hai Nguyen (2021). Vietnamese Students' Perceptions of Moral Values: An Assessment by Students at An Giang University. Universal Journal of Educational Research, 9(11), 1814 - 1825. DOI: 10.13189/ujer.2021.091102.

Copyright $\bigcirc 2021$ by authors, all rights reserved. Authors agree that this article remains permanently open access under the terms of the Creative Commons Attribution License 4.0 International License

\begin{abstract}
The purpose of this study is to investigate the students' evaluation of the traditional moral education model by six factors including patriotism; Love for people and humanity; The spirit of solidarity; The virtues of diligence and thrift; The Fond of learning; The love of nature and protection of the environment. A questionnaire survey was distributed to 293 students at An Giang University. Experimental results show that most students attach importance to traditional moral education. There are two factors including love for nature and environmental protection; Being fond of learning in the model has influenced the traditional moral education for students at An Giang University, Vietnam. Comparing the two groups of males and females, their satisfaction with the elements of traditional moral education is nearly the same. Comparing 8 groups of students from 8 faculties in terms of their satisfaction with 6 elements of traditional moral education is almost the same, it is not much different. The findings of this study have theoretical and practical implications for moral education in Vietnam. Proposals made for university administrators and educators were discussed.
\end{abstract}

Keywords Traditional Ethics, Vietnam, Patriotism, Humanity, Diligence, Solidarity

\section{Introduction}

Traditional moral value education has an important role to pass on to students good moral values [6]. It helps students realize moral values, and benevolence $[14,18]$. Educating students on traditional national moral values will contribute to strengthening and promoting those values, forming necessary personality qualities [16]. Education of traditional moral values helps students understand the national spiritual culture, enhance patriotism and pride in the history of the nation.

Paying attention to traditional ethics is a characteristic of the Vietnamese nation. It is a valuable cultural and spiritual of Vietnamese who should preserve, supplement the appropriate content, and promote. For example, patriotism does not only stop at the concept of protecting the country, but it is also the will to enrich oneself, family, and society, contributing to the development of the country out of poverty [34]. Human love is not only expressed in the attitude of respecting and protecting people. We should know how to protect the living environment, respect the rules in community activities. Fight against evil, injustice, encroachment on the legitimate interests of people, and we should bring joy to people.

Traditional moral education for students is to contribute to equipping students with pure moral qualities, strong will, and proper manners. This is the basis for developing students' capacity [25]. In the students' personality, self-consciousness is only really promoted when students have patriotism, national pride, idealistic living, nostalgia, diligence, and creativity in learning and scientific research. Traditional moral education will help students deeply understand traditional moral values as noble spiritual values [43], creating diversity in Vietnamese identity. We 
should build a generation of students with good moral qualities including patriotism, love of labor, humanity, living for the collective, community, love of freedom, love of peace, love of nature, environmental protection.

Traditional moral education contributes to the development of the competency factor in students' personalities [30]. Competence in human personality is formed and developed on the basis of innate factors genetics and social factors. Through education and training, that innate capacity element forms outstanding capabilities (cognitive capacity and practical capacity), it must come from the requirements of society [29]. In which, there are moral standards of society that regulate the cognitive and practical capacity of people to develop in accordance with the requirements of history.

Among the traditional moral values, patriotism is the highest value, and educating students about patriotism is contributing to the formation of cognitive and practical capacity [46]. Patriotism is expressed in social activism by students. The students' active social activities facilitate the development of capacity, that is, the students' abilities are promoted, especially the positivity, initiative, and creativity in life, learning to create effective activities, and the right motive for action [59]. From there, students actively and voluntarily express patriotic feelings and realize patriotic values in life. To be patriotic is to contribute one's ability to the country's development and civilization. Patriotism means loving people, protecting the living environment, working together to build a green - clean - beautiful country. To be patriotic is to obey the law, stay away from social evils, and live a healthy life [26]. At the same time, it is the positivity, self-awareness, creativity, spirit of overcoming difficulties and suffering in learning to rise to grasp and master scientific and technological knowledge.

Development is a self-made process, and internal strength is the decisive factor. The ability of students does not come naturally, it must be due to each student's own efforts in learning and training to create certain competencies [22]. Educating the nation's industriousness is to help students have the cognitive ability to persevere and be patient to overcome all difficulties to achieve the set goals. Under the current conditions, students have to work hard and study hard to accumulate knowledge and skills to create personal competencies to contribute to social activities and preparefor the future.

Diligence and hard work are necessary factors to form students' competencies, that capacity must lie in the process of accumulating knowledge in school and practical knowledge of life. In order to acquire such knowledge, students are required to be diligent in studying, and on the other hand, must also actively participate in social activities. Educating the value of industriousness and hard work is a necessary requirement, creating distinct strengths that are easy to enter into the awareness and actions of each student. It is no longer at the level of self-consciousness but becomes voluntary, they commit themselves to overcoming the harsh challenges of social life [44].

In Vietnam, the economy is following the market mechanism, which stipulates that people must be dynamic, agile and competitive. Many Vietnamese have pursued personal interests that they can give up traditional moral values. There has been a change in the concept of life, the lifestyle of Vietnamese people, and students. There is a tendency to change some traditional moral values in society, some students for their own benefit ignore the interests of the collective and the community. The gap between the rich and the poor is increasing, besides the loss of love for people, and the indifference and insensitivity to human suffering.

The impact of globalization has led to the threat the traditional moral values and the intrusion of modern values that are not suitable for the cultural and ethical circumstances of Vietnamese people. Many students have been influenced by the concept and lifestyle that values individual freedom, they let loose in life, and disregard morality and public opinion.

In recent years, educational institutions have not paid enough attention to the issue of traditional moral education to students. Many students lack the skills to choose the right moral standards and lifestyle. Therefore, in their ethical behavior, their lifestyle has "deviation" from the traditional moral values of the nation.

Nguyen realized that globalization could wrongfully change many values from our way of life that followed noble and fine humanistic ideal cultivated by our ancestors after thousands of years, and therefore deteriorated social values [40]. With the same point of view Huyen, in her article "Globalization and the risk of ethic and lifestyle deterioration to Vietnamese people at present", warned about the risks of globalization to ethical lifestyle of Vietnamese people [41].

Therefore, this study investigates students' evaluation of traditional moral education; Therefore, answers to the following questions will be sought including:

1. To what extent do students satisfy with traditional moral education?

2. What factors students' satisfaction with traditional moral education?

3. Are students satisfied with traditional moral education difference between groups?

\section{Literature Review}

\subsection{Vietnamese Traditional Moral Value}

Traditional moral values are an important part of the entire spiritual value system of the Vietnamese nation. Vietnamese traditional moral values are typical moral values of Vietnamese people. Ethical values regulate and 
evaluate human behavior towards people, people with society, they are implemented by social norms, by personal beliefs, and the power of public opinion [58]. Moral value is also a historical category, it has a process of formation and development, it is influenced by society. Ethical values progress and develop when the system is positive, humanitarian, and progressive.

In moral values, there is often a combination of traditional values and modern values [60]. Traditional moral values are good moral values formed in the process of nation-building and defending the country of the Vietnamese nation and handed down from generation to generation. Moral values have a humanistic and community nature, which is a combination of national quintessence [8]. Traditional ethical values of Vietnamese people include being rich in patriotism, love for people, humanity, solidarity, industriousness, intelligence, creativity, studiousness, and love of nature. Moral values have deeply penetrated into the lives of Vietnamese people and become respected standards for stability.

\subsection{Educating Traditional Moral Values for Vietnamese Students}

Traditional moral values include sustainable values [55], the quintessence of the ethnic groups in Vietnam cultivated through the history of thousands of years of struggle to build and defend the country. The national identity is passionate patriotism, the will to self-reliance, the spirit of solidarity, the sense of community that connects individuals - families - villages - the Fatherland. Traditional moral values include patriotism; Love for people and humanity; Solidarity; Industriousness, thrift; Fond of learning; Love of nature.

Patriotism is a natural human emotion, it was born and developed in the history of the nation [2]. Patriotism has great value [19], it is a strong spiritual motivation to motivate many Vietnamese to take strong action in building the country and protecting the dignity of the Vietnamese people.

In their special circumstances, the Vietnamese have forged a strong patriotism, a patriotic spirit that transcends common sentiments, which has become a sense of responsibility for the community and the nation. Patriotism has becomea morality, it goes deep into the consciousness of every Vietnamese person, it becomes the standard of society [11]. Patriotism has great power in educating and promoting the national spirit for generations of Vietnamese people.

Patriotism and national pride have become a tradition of the Vietnamese nation. Patriotism education aims to form and develop students' personalities about love for the country, loyalty, and aspiration to serve the interests of the Fatherland and the people [50].

The love for people and humanity of the Vietnamese people is formed and developed in the relationship between family members, village communities, and ethnic communities. In behavior, Vietnamese people often take humanity and love asthe foundation, it is developed into a philosophy of life of Vietnamese people. The love of people in the moral tradition of the Vietnamese people contains forgiveness for the bad guys when they realize their mistakes. This is one of the unique features that show humanity and love for people in the Vietnamese nation.

Globalization and the market economy have made certain changes in the moral values of the society, the temptation of money has clouded, and moral values are gradually going down [15]. Therefore, educating moral values for students should acquire new moral values, while inheriting traditional moral values, towards the truth, honesty, and perfection. Educating students to love and respect people for the formation and development of student personality includes a goodwill attitude [20]. We should serve the interests of people, and bring freedom and happiness to people, everyone is equal in society, everyone is free.

The virtues of diligence and thrift are outstanding moral values in the traditional value system of the Vietnamese nation. With industriousness and diligence, Vietnamese people have created great and valuable labor results. Hard work and thrifthave gone deep into people's subconscious, it has become a virtue of Vietnamese people. Hard work is the source of all values [54]. Appreciating labor, Vietnamese people always criticize laziness. In working and studying, Vietnamese people always supplement their intellectual weakness by the expression "industrious compensates for intelligence". From life, Vietnamese people have learned from experience that industriousness must always go hand in hand with thrift.

Educating the traditional moral values of diligence and thrift for students is to educate the virtues of diligence and creativity in learning; thrifty in daily life, optimistic in life. Educating students to work hard, cherish the values they are enjoying, labor plays an important role in the development of themselves and humanity [56].

The spirit of solidarity, in the history of national construction, Vietnam has built strong solidarity, it has become one ofthe good traditional spiritual values, one of the driving forces and great strength of the Vietnamese people.

Natural conditions dictate that people who want to survive must work together, a community in the region, and a senseof association into a unified ethnic community [37]. The requirement to join forces in production, in the struggle with nature over a historical period is the basic factor creating a sense of solidarity.

The process of studying and training at the university is not only the process of educating and training students with moral qualities, the ability to participate in the production process of society, but also preparing them for the ability to enter different spheres of social life such as 
politics, culture, family, communication [36]. Educate students about their responsibility to the community, they should have a volunteer spirit [10].

The spirit of studiousness and respect for human morality is a tradition of the Vietnamese nation [32], they have valuable experience in the field of education, which is to educate students in the spirit of studiousness, respect for teachers. The tradition of "respecting the teacher" has existed for a long time and it has become a morality of the Vietnamese people. In Vietnamese history, teachers are always respected and admired [53]. Learners believe that not only learn in school but have to learn anytime, anywhere, everything, they learn through social activities, in the family, customs, practices, festivals. Activities of educating people according to the goal of unifying learning are to be human and serve society [31].

In the context of globalization and international integration, expanding cultural and educational exchanges with countries around the world, absorbing reasonable factors of progress, civilization, and educational achievements of mankind [48]. It becomes the key element to education for development. Educating students in a spirit of studious, and respect has become an urgent requirement. In the era of the knowledge economy, it is a combination of moral qualities and competence [38]. To do that, we should educate students with a sense of self-discipline, creativity, in learning and scientific research in the spirit of action "study - creativity integration - development".

The love nature and protect the environment, Vietnamese love nature, they want to live in harmony with nature, they live according to nature because nature is the source of human life. Today, the love of nature and the protection of the living environment are reflected in the exploitation of resources in a reasonable way, exploitation associated with protection and regeneration [51].

Educating students to realize that protecting the environment and natural resources is an integral element of development. When being educated, students will be aware of their obligations to protect the environment by taking concrete and practical actions [13]. Nowadays, environmental protection is a matter of concern all over the world. Before the development of modern industry, the living environment of people is in danger of being seriously polluted, it requires us to protect the environment through specific activities such as keeping public places clean, participate in environmentalprotection campaigns.

\subsection{Research Theory}

Currently, the content of traditional moral education for students is of interest to some researchers and educators. In the trend of globalization, the market economy has created socio-economic development. However, its flip side has affected the morals of some students. There are a few studies that have proposed the traditional moral education model for students.

According to Pham and Bui, we live in an era of globalization that is full of competition and change. In this change process, it is essential to acknowledge the nature and impact of the process to help us reduce risk. Meanwhile, it is important to develop a sustainable economy, absorb the cultural quintessence of humanity, and at the same time prevent the risks of social moral degradation [45]. In that context, the education of ethics and values for students has become increasingly necessary and it is necessary to focus on practical content. It includes education of patriotism and filial piety for parents; Education of diligence, love of working, and frugality; Education of traditions "be deferential to teacher and respected for morals", unification and loving mutual support; Education of diligence in learning, modesty, and politeness; Education of discipline, tolerance, sincerity, and trustworthiness; Education of courageous spirit, dedication, fairness, and impartiality.

According to Le, when globalization is an inevitable trend, it increases the cultural conflict of each country. Some traditional values of the Vietnamese people are being obscured and distorted [33]. In particular, some values traditional in the family are no longer respected, even at the risk of being broken. Students are an important resource that determines the development and future of the country. Therefore, educating students on traditional moral values is necessary. Traditional moral values are a core part of Vietnam's traditional spiritual values. It is the love for family; the care and help of each other in times of difficulty and tribulation; Sharing the joys and sorrows of life together.

According to Nguyen, globalization and international integration have made positive socio-economic contributions. However, it is also the influencing factors that change traditional spiritual and moral values. Many manifestations of negative change such as downplaying traditional moral values and fine customs; Social evils are increasing and affecting students [39]. Therefore, the education of Vietnamese traditional moral values for students should be concerned. Some traditional moral values that should be educating include patriotism; Human love; Community solidarity spirit; Virtue of diligence, thrift, honesty; Studious, creativity.

\section{Research Methodology}

\subsection{Procedure and Instrumentation}

On the basis of theoretical research, traditional ethical conceptual frameworks provide information for surveys. In order to be able to identify elements of the traditional moral education for students, the study reviewed the theoretical framework and held group discussions with 15 students and 5 lecturers. During the focus group 
discussions, the students and lecturers were provided with lists of traditional moral education contents and asked to give their opinions on ideas to improve the questionable, scale, and add the missing elements to the list. The consensus reached at the end of the period led to the identification of six factors (corresponding to 27 observed variables) including

\section{Patriotism (PAT)}

PAT1: Love the village where we were born

PAT2: Proud of Vietnamese culture

PAT3: Proud of the Vietnamese people

PAT4: Proud of Vietnam's tradition of building and defending the country

PAT5: Look forward to trying to contribute to the construction of the country

\section{The love for people and humanity (HUM)}

HUM1: Empathize, understand everyone's difficulties

HUM2: Share joy, and help people in trouble

HUM3: Respect human dignity, their individual characteristics

HUM4: Create opportunities for everyone to create and develop

HUM5: Everyone has the opportunity to learn and grow

\section{The spirit of solidarity (SOL)}

SOL1: Lifestyle in harmony with the community

SOL2: Volunteer to help people, the community

SOL3: Cooperation, and mutual support for development

SOL4: Responsible lifestyle to the community

SOL5: Prioritize community interests over personal interests

\section{The virtues of diligence and thrift (DIL)}

DIL1: Work hard, and be creative

DIL2: Appreciate existing material values

DIL3: Love life, hope everything goes well in the future

DIL4: Work honestly by yourself

\section{Fond of learning (LEA)}

LEA1: Respect teachers, cherish friends

LEA2: Actively absorb everything good it has value

LEA3: Diligence to study, research, create

LEA4: Study diligently will bring a good future

The love of nature and protect the environment (NAT)

NAT1: Plant trees to protect the environment
NAT2: Garbage collection and treatment

NAT3: Save electricity and water

NAT4: Celebrate World Environment Day

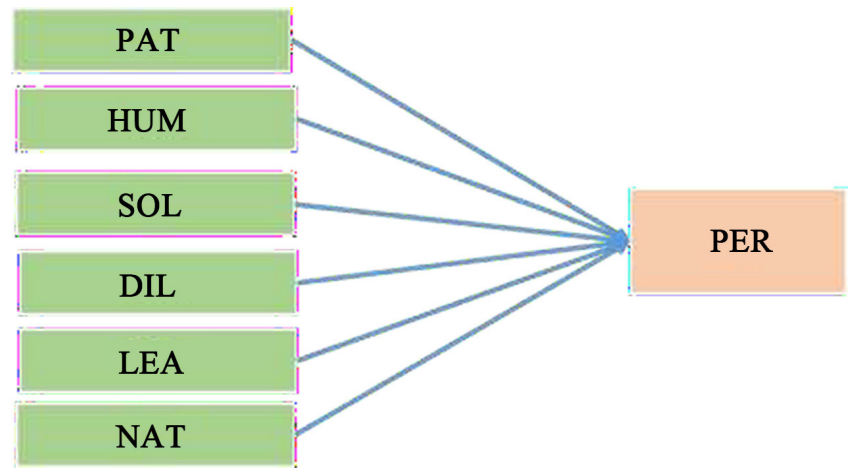

PAT: Patriotism; HUM: The love for people and humanity; SOL: The spirit of solidarity; DIL: The virtues of diligence and thrift; LEA: Fond of learning; NAT: The love of nature and protect the environment; PER: Student's evaluation of moral education

Figure 1. Student Evaluation of Moral Education Model

Based on the preliminary discussion of results, a questionnaire was then developed. The survey consisted of demographic questions and 29 Likert items. Demographic questions seek information about gender, faculty students from respondents. Meanwhile, questions on a 5-point Likert scale are used to explore, 1 (Strongly disagree), 2 (Disagree), 3 (Neutral), 4 (Agree), 5 (Totally agree) to show how important it is.

\subsection{Research Sample}

Data collection took place between May and June 2021. Methods of conduct students responded directly to the questionnaire. The study was carried out at An Giang University, Vietnam National University Ho Chi Minh City, Vietnam. The questionnaire was distributed to 300 students. There are 293 valid response forms were collected, including 153 males and 140 females. There are $7.5 \%$ from Faculty of Agriculture - Natural Resources; There are 14\% from Faculty of Economics - Business Administration; There are 6.5\% from Faculty of Pedagogy; There are $16.4 \%$ from Faculty of Law and Political Science; There are 9.9\% from Faculty of Engineering Technology - Environment; There are $21.5 \%$ from the Faculty of Information Technology; There are 9.2\% from the Faculty of Tourism and Culture - Arts; There are 15\% from the Faculty of Foreign language. It is shown in Table 1. 
Table 1. Description of the survey form

\begin{tabular}{|c|c|c|}
\hline Research factor & Number of people & Percentage \\
\hline 1. Gender & 293 & $100 \%$ \\
\hline Male & 153 & 52.2 \\
\hline Female & 140 & 47.8 \\
\hline 2. Faculty & 293 & $100 \%$ \\
\hline Faculty of Agriculture - Natural Resources & 22 & 7.5 \\
\hline Faculty of Economics - Business Administration & 41 & 14.0 \\
\hline Faculty of Pedagogy & 19 & 6.5 \\
\hline Faculty of Law and Political Science & 48 & 16.4 \\
\hline Faculty of Engineering - Technology - Environment & 29 & 9.9 \\
\hline Faculty of Information Technology & 63 & 21.5 \\
\hline Faculty of Tourism and Culture - Arts & 27 & 9.2 \\
\hline Faculty of Foreign language & 44 & 15.0 \\
\hline
\end{tabular}

Table 2. Reliability estimates

\begin{tabular}{|c|c|c|c|}
\hline Factors & Observed variables & Cronbach's Alpha & Corrected Item-Total Correlation \\
\hline PAT & PAT1, PAT2, PAT3, PAT4, PAT5 & .831 & $>0.3$ \\
\hline HUM & HUM1, HUM2, HUM3, HUM4, HUM5 & .693 & $>0.3$ \\
\hline SOL & SOL1, SOL2, SOL3, SOL4, SOL5 & .782 & $>0.3$ \\
\hline DIL & DIL1, DIL2, DIL3, DIL4 & .865 & $>0.3$ \\
\hline LEA & LEA1, LEA2, LEA3, LEA4 & .857 & $>0.3$ \\
\hline NAT & NAT1, NAT2, NAT3, NAT4 & .906 & $>0.3$ \\
\hline
\end{tabular}

\subsection{Data Analysis}

Responses from the survey were coded and entered in SPSS Version 20. Analysis of students' evaluation of ethical education elements at An Giang University is conducted through 3 steps. Step 1: Check the reliability of the scale through the reliability coefficient Cronbach's Alpha. Step 2: Exploratory factor analysis (EFA) to test the factors. Step 3: Use a linear regression model to determine the degree of influence of factors on moral education for students at An Giang University. Step 4: Analyze Independent-Samples T-Test to test the mean difference in gender, One-way ANOVA analysis to test the mean difference between faculties.

\section{Results}

\subsection{Check the Reliability of the Scale}

Testing the reliability of the factor scale consisting of 27 observed variables, Table 2, the results of testing the reliabilityof Cronbach's Alpha of the component variables, shows that the coefficients of Cronbach's Alpha are all greater than the minimum level of 0.6 and variable of Corrected Item-Total Correlation $>0.3$. If a measurement variable has Corrected Item-Total Correlation $\geq 0.3$, then the variable meets the requirements [42] and Cronbach's Alpha coefficient of 0.6 or higher, the scale is eligible. Therefore, these observed variables are eligible for factor analysis.

\subsection{Exploratory Factor Analysis (EFA)}

After checking the reliability of the scale, Exploratory Factor Analysis (EFA) was performed to determine the correlation between the factors and the loading coefficient of Kaiser-Meyer-Olkin $(\mathrm{KMO})=0.812$ (satisfies $0.55 \leq$ $\mathrm{KMO} \leq 1)$, Sig Barlett Test $=0.000(<0.05)[17]$. Table 3 shows a good correlationbetween the observed variables.

Results of exploratory factor analysis, 6 factors with Eigenvalue $>1$ were drawn from 27 observed variables andCumulative $=63.846 \%$.

Table 3. KMO and Bartlett's Test

\begin{tabular}{|c|c|c|}
\hline \multicolumn{2}{|c|}{$\begin{array}{c}\text { Kaiser-Meyer-Olkin Measure of Sampling } \\
\text { Adequacy. }\end{array}$} & .812 \\
\hline \multirow{3}{*}{$\begin{array}{c}\text { Bartlett's Test of } \\
\text { Sphericity }\end{array}$} & Approx. Chi-Square & 4126.906 \\
\cline { 2 - 3 } & $\mathrm{df}$ & .351 \\
\cline { 2 - 3 } & Sig. & .000 \\
\hline
\end{tabular}

The Rotated Component Matrix, table 4 showed that the 27 observable variables loaded on 6 factors and there werechanges to the position of the variables. 
Table 4. Rotated Component Matrix

\begin{tabular}{|c|c|c|c|c|c|c|}
\hline & \multicolumn{6}{|c|}{ Component } \\
\hline & 1 & 2 & 3 & 4 & 5 & 6 \\
\hline NAT4 & .895 & & & & & \\
\hline NAT2 & .883 & & & & & \\
\hline NAT1 & .863 & & & & & \\
\hline NAT3 & .856 & & & & & \\
\hline PAT5 & & .810 & & & & \\
\hline PAT1 & & .766 & & & & \\
\hline PAT2 & & .713 & & & & \\
\hline PAT3 & & .704 & & & & \\
\hline PAT4 & & .557 & & & & \\
\hline LEA4 & & & .874 & & & \\
\hline LEA1 & & & .823 & & & \\
\hline LEA2 & & & .800 & & & \\
\hline LEA3 & & & .725 & & & \\
\hline DIL4 & & & & .896 & & \\
\hline DIL2 & & & & .823 & & \\
\hline DIL1 & & & & .802 & & \\
\hline DIL3 & & & & .657 & & \\
\hline SOL5 & & & & & .829 & \\
\hline SOL2 & & & & & .718 & \\
\hline SOL1 & & & & & .708 & \\
\hline SOL3 & & & & & .649 & \\
\hline SOL4 & & & & & .510 & \\
\hline HUM1 & & & & & & .749 \\
\hline HUM2 & & & & & & .655 \\
\hline HUM4 & & & & & & .637 \\
\hline HUM3 & & & & & & .589 \\
\hline HUM5 & & & & & & .576 \\
\hline
\end{tabular}

Table 5. Revised factors and variables

\begin{tabular}{|c|c|c|}
\hline Factors & Observed variables & Variable types \\
\hline PAT & PAT1, PAT2, PAT3, PAT4, PAT5 & Independent \\
\hline HUM & HUM1, HUM2, HUM3, HUM4, HUM5 & Independent \\
\hline SOL & SOL1, SOL2, SOL3, SOL4 & Independent \\
\hline DIL & DIL1, DIL2, DIL3, DIL4 & Independent \\
\hline LEA & LEA1, LEA2, LEA3, LEA4 & Independent \\
\hline NAT & NAT1, NAT2, NAT3, NAT4 & Dependent \\
\hline PER & PER1, PER2, PER3 \\
\hline
\end{tabular}

Thus, the EFA outputs generate a set of factors and observed variables. Table 5 can fit the data and model.

\subsection{Results Analysis Moral Education Model}

When independent and dependent variables could be identified, a multiple regression model was used to determine the overall fit of the model and the relative contribution of each predictor to the total variance. The Model Summary in Table 6, R2 (Adjusted R Square) = 0.688 showed that the independent variables NAT, HUM, LEA, DIL, SOL, PAT explained $68.8 \%$ of the variation in 
dependent variable PER. The remaining $42.2 \%$ of the change is indicated by other variables outside the studied model.

Table 7. Check whether the overall regression model fits the data. This shows that the independent variables predict statistically significant for the dependent variable, Sig. $=.000(<.005)$ compared to the $5 \%$ significance level, so setting upthe regression model is appropriate.

The correlation coefficient and variance were then tested to measure the effect of collinearity among the variables in the regression model. As shown in Table 8, the
Collinearity Statistics (VIF) of all independent variables is lower than 10, indicating that there is no autocorrelation, multicollinearity in the model.

Four independent variables PAT, HUM, SOL, DIL have no statistical significance. The remaining variables LEA, NAT has statistical significance (Sig. $<0.05)$ and Standardized Coefficients Beta $>0$, demonstrating a positive influence on thedependent variable, Table 8 .

From Table 8, the new model for the data is: PER = $0.789 * \mathrm{NAT}+0.085 * \mathrm{LEA}$

Table 6. Model Summary

\begin{tabular}{|c|c|c|c|c|c|}
\hline Model & R & R Square & Adjusted R Square & Std. Error of the Estimate & Durbin-Watson \\
\hline 1 & $.833^{\mathrm{a}}$ & .694 & .688 & .37465 & 1.893 \\
\hline
\end{tabular}

a. Predictors: (Constant), NAT, HUM, LEA, DIL, SOL, PAT

b. Dependent Variable: PER

Table 7. ANOVA

\begin{tabular}{|c|c|c|c|c|c|c|}
\hline \multicolumn{2}{|c|}{ Model } & Sum of Squares & df & Mean Square & F & Sig. \\
\hline & Regression & 91.156 & 6 & 15.193 & 108.238 & .000 \\
\cline { 2 - 7 } & Residual & 40.144 & 286 & .140 & & \\
\cline { 2 - 6 } & 131.300 & 292 & & & \\
\hline
\end{tabular}

a. Dependent Variable: PER

b. Predictors: (Constant), NAT, HUM, LEA, DIL, SOL, PAT

Table 8. Coefficients

\begin{tabular}{|c|c|c|c|c|c|c|c|}
\hline \multirow{2}{*}{ Model } & \multicolumn{2}{|c|}{ Unstandardized Coefficients } & \multirow{2}{*}{$\begin{array}{c}\begin{array}{c}\text { Standardized } \\
\text { Coefficients }\end{array} \\
\text { Beta }\end{array}$} & \multirow{2}{*}{$\mathrm{t}$} & \multirow{2}{*}{ Sig. } & \multicolumn{2}{|c|}{ Collinearity Statistics } \\
\hline & B & Std. Error & & & & Tolerance & VIF \\
\hline (Constant) & .542 & .198 & & 2.734 & .007 & & \\
\hline PAT & .055 & .039 & .059 & 1.428 & .154 & .625 & 1.600 \\
\hline HUM & .050 & .042 & .043 & 1.185 & .237 & .819 & 1.222 \\
\hline SOL & .040 & .043 & .036 & .923 & .357 & .720 & 1.388 \\
\hline DIL & .005 & .031 & .000 & .001 & .999 & .718 & 1.392 \\
\hline LEA & .082 & .035 & .085 & 2.338 & .020 & .817 & 1.224 \\
\hline NAT & .661 & .029 & .789 & 22.927 & .000 & .902 & 1.108 \\
\hline
\end{tabular}

Table 9. Independent Samples Test

\begin{tabular}{|c|c|c|c|c|c|c|c|c|c|c|}
\hline & \multicolumn{2}{|c|}{$\begin{array}{c}\text { Levene's Test for } \\
\text { Equality of } \\
\text { Variances }\end{array}$} & \multicolumn{7}{|c|}{ t-test for Equality of Means } \\
\hline & & \multirow[t]{2}{*}{$\mathrm{F}$} & \multirow[t]{2}{*}{ Sig. } & \multirow[t]{2}{*}{$\mathrm{t}$} & \multirow[t]{2}{*}{$\mathrm{df}$} & \multirow[t]{2}{*}{$\begin{array}{c}\text { Sig. } \\
\text { (2-tailed) }\end{array}$} & \multirow[t]{2}{*}{$\begin{array}{c}\text { Mean } \\
\text { Difference }\end{array}$} & \multirow[t]{2}{*}{$\begin{array}{l}\text { Std. Error } \\
\text { Difference }\end{array}$} & \multicolumn{2}{|c|}{$\begin{array}{l}95 \% \text { Confidence } \\
\text { Interval of the } \\
\text { Difference }\end{array}$} \\
\hline & & & & & & & & & Lower & Upper \\
\hline \multirow{2}{*}{ PER } & $\begin{array}{c}\text { Equal } \\
\text { variances } \\
\text { assumed }\end{array}$ & 1.082 & .299 & -.159 & 291 & .873 & -.01253 & .07856 & -.16714 & .14209 \\
\hline & $\begin{array}{c}\text { Equal } \\
\text { variances not } \\
\text { assumed }\end{array}$ & & & -.160 & 290.876 & .873 & -.01253 & .07832 & -.16667 & .14162 \\
\hline
\end{tabular}




\subsection{Analysis of Variance (ANOVA), and Test (T-Test) for Gender}

Comparing of differences in the satisfaction between males and females gender by their assessment of moral education.

Table 9 shows, analysis of the Independent Samples Test has Sig. $=0.299(>0.05)$. This means that the variances of both the male and female groups are equal. Table 9 also shows that there is no difference between groups male and groups women. Value Sig. (2-tailed) = $0.873(>0.05)$. That is, the satisfaction of moral education of groups male and groups women is the same.

Comparing of differences in the satisfaction between the eight groups of students by their assessment of moral education.

Table 10. Test of Homogeneity of Variances

PER

\begin{tabular}{|c|c|c|c|}
\hline Levene Statistic & df1 & df2 & Sig. \\
\hline 1.277 & 7 & 285 & .262 \\
\hline
\end{tabular}

Table 10 shows Sig. $=0.262(>0.05)$. This means that the variance of the eight groups students on the satisfaction of moral education has no difference. When Table 10 has Sig. $=0.262(>0.05)$, ANOVA table will be used, Table 11 shows Sig. $=0.277(>0.05)$. Thus, the satisfaction of students in 8 groups the assessment of moral education is almost the same. Their satisfaction for 6 factors of the moral education has there was no difference.

Table 11. ANOVA

PER

\begin{tabular}{|c|c|c|c|c|c|}
\hline & $\begin{array}{c}\text { Sum of } \\
\text { Squares }\end{array}$ & df & $\begin{array}{c}\text { Mean } \\
\text { Square }\end{array}$ & F & Sig. \\
\hline Between Groups & 3.900 & 7 & .557 & 1.247 & .277 \\
\hline Within Groups & 127.399 & 285 & .447 & & \\
\hline Total & 131.300 & 292 & & & \\
\hline
\end{tabular}

\section{Discussion}

The original model including 6 factors is proposed for moral education for students. It is the moral values that include patriotism; The love for people and humanity; The spirit of solidarity; The virtues of diligence and thrift; The fondness of learning; The love of nature and protect the environment. Statistical analysis using EFA and linear regression model shows that 6 factors are predicted to have an impact on moral education for students. There are two factors including love for nature and environmental protection have Standardized Coefficients Beta $=0.789$; Fond of learning has Standardized Coefficients Beta = 0.085. These two factors have an impact on student satisfaction in traditional moral education.

The findings will help fill in gaps in the theory and practice of traditional moral education for students. The assessment of learners is an honest reflection of the results of moral teaching, it has a difference between theory and practice [9]. The review of the content of ethics teaching should be set out, should be added to the content suitable to the reality and psychology of students. We should reconsider the method of teaching is effective.

For many years in Vietnam, educational innovation activities have been paid more attention by educational institutions and universities to students' learning, investing in material and technical facilities to serve the needs of students $[30,47]$. Teachers and lecturers often innovate teaching methods in the direction that learners are the center of the teaching-learning process. Learners need a lot of time to research and discuss [57]. In addition, extracurricular activities, student clubs, and movement activities will help students acquire knowledge, discover knowledge, and create [62]. When the human factor is given special importance, the intellectual potential along with the spiritual and moral strength of the human being is enhanced and strongly promoted in all areas of society [7]. Improving the quality and effectiveness of moral education for students is a regular requirement of the educational work, as well as an urgent requirement to improve the quality of education [24].

The teacher's constructive role is shown in organizing and guiding learning activities in a friendly environment and problem situations in order to encourage learners to actively participate [52]. It is advisable to provoke and encourage learners to assert their own needs and abilities, and at the same time forge learners' habits and self-study ability [12]. Students will promote their potential and effectively apply the accumulated knowledge and skills, thereby creating a premise for comprehensive self-development.

Test the difference by means of Independent Sample $\mathrm{T}$-Test between the male and female groups, on the assessment of the two groups on moral education for students. Value Sig T-Test $=0.873(>0.05)$ concluding that there is no difference in the satisfaction level of respondents of different genders. Test the difference by One-Way ANOVA to see if there are differences in student satisfaction among the eight groups. Value Sig in the table ANOVA $=0.277(>0.05)$, concluding that there is no difference in the satisfaction level in the moral education of the respondents from the eight groups.

There should be a harmonious combination between the content and the method of moral teaching [3]. Another concern is the learning method, the self-study method so that learners can learn for life, it is identified as an important factor in the process of educating students [1]. At the same time, educate students on moral values, cultural traditions, and good lifestyles [49]. It is recommended to build a column on ideal and ethical education, honoring outstanding student examples in learning, training, and social work. 
Universities should create a democratic, healthy and friendly environment, and implement cultural codes of conduct in schools. Education and training institutions should arrange and use playgrounds, training grounds, and upgrade facilities to serve the activities of hobby clubs in order to meet the demand for healthy entertainment and recreation [4]. If the issuesjust discussed are solved well, it will be directly proportional to the improvement of the quality of education, and the quality of traditional moral education will be more effective.

\section{Conclusions}

In the past, traditional moral education for students was a theoretical research model. The results of the study showed that a large number of students were satisfied with elements of moral education. Students are quite satisfied with the two-factor of the love for nature and environmental protection, and the fondness of learning. In addition, this study provides insights into students' perceptions of moral education. Comparing the satisfaction of students between the 2 groups of males and females, the research results show that their satisfaction is almost the same. The second comparison is the satisfaction of students in 8 groups, and the results show that their satisfaction is almost the same. The research results help educational administrators understand the relationship between the moral curriculum and the needs of students. Educational administrators should make adjustments in teaching content, teaching methods, environment, and circumstances that affect learners' needs. In addition, the findings in the study also help researchers to carry out follow-up studies, they need to collect more samples to conduct in a large area or across the country to have statistics on moral education.

\section{Contribution/Originality}

The objective of this study is to identify the traditional ethical education factors for students, the students' evaluation ofthese factors in the satisfaction of educational goals. The findings can be used by lecturers to adjust the objectives and methods of teaching traditional ethics to students in Vietnamese universities.

\section{REFERENCES}

[1] Ann, C. "Toward a Bold Agenda for Moral Education". Philosophical Inquiry in Education, 26,(2), 117-123. 2019. https://journals.sfu.ca/pie/index.php/pie/article/view/1119

[2] Anatoli, R. "Tendencies in Civic Education in Russia: The Perception of Patriotism among Secondary School Teachers". Journal of International Social Studies, 6(2),
109-124. 2016. https://www.iajiss.org/index.php/iajiss/arti cle/view/245

[3] Cheung, C., and Lee, T. "Contributions of moral education lectures and moral discussion in Hong Kong secondary schools".

[4] Social Psychology of Education, 13, 575-591. 2010. https://doi.org/10.1007/s11218-010-9127-x

[5] Clark, P. "The Just Community Approach to Moral Education". Journal of Moral Education, 17(3), 195-208. 1988.https://doi.org/10.1080/0305724880170304

[6] Cadotte, E. R., Woodruff, R. B., and Jenkins, R. L. "Expectations and norms in models of consumer satisfaction". Journal of Marketing Research, 24(3), 305-314. 1987. https://doi.org/10.2307/3151641

[7] Darcia, N. "Moral education in a time of human ecological devastation". Journal of Moral Education, 50(1), 55-67. 2021.https://doi.org/10.1080/03057240.2020.1781067

[8] Do, N. M. "An overview of strategic responses of Vietnamese higher education institutions", International Journal of Educational Management, 34(1), 35-44. 2020. https://doi.org/10.1108/IJEM-02-2019-0074

[9] Dung, H. D. "Moral education or political education in the Vietnamese educational system?". Journal of Moral Education, 34(4), 451-463. 2005.https://doi.org/10.1080/03 057240500414733

[10] Elaine, D., and Joanne, O. "The impact of education level and type on moral reasoning". Irish Educational Studies, 32(3), 377-393. 2013. https://doi.org/10.1080/03323315.20 13.823273

[11] Fahed, Z. "Teaching Spiritual Solidarity through "Human Books"'. Teaching Theology \& Religion, 23(3), 202-208. 2020.https://doi.org/10.1111/teth.12551

[12] Faiz, M., and Avci, E. K. "The Patriotic Attitudes of the Prospective Teachers". International Journal of Psychology and Educational Studies, 7(1), 124-134. 2020. http://www.ijpes.com/

[13] Fang, Y. "On the Moral Characteristics in the Perspective of Caring Ethics". Open Journal of Social Sciences, 8, 106-114. 2020.https://doi:10.4236/jss.2020.89007

[14] Fan, Y., Jing, L., and Thomas, C. "From intimidation to love: Taoist philosophy and love-based environmental education".

[15] Educational Philosophy and Theory, 51(11), 1117-1129. 2019. https://doi.org/10.1080/00131857.2018.1564659

[16] Gordon, C. R. "Moral education in revolutionary society". Theory Into Practice, 14(4), 258-263. 1975 https://doi.org/10.1080/00405847509542584

[17] Gutierrez, D., Dorais, S., Smith, J. M., and Mutanguha, F. "Humanity Education as a School-Based Intervention for Healing". Journal of School-Based Counseling Policy and Evaluation, 1(3), 63-70. 2019. https://doi.org/10.25774/6rg w-bn52

[18] Hanan, A. A. "Assessing virtue: measurement in moral education at home and abroad". Ethics and Education, 11(3), 310-325. 2016.https://doi.org/10.1080/17449642.2016.124 0385 
[19] Hair, J. F., Tatham, R. L., Anderson, R. E., and Black, W. "Multivariate data analysis" (6th ed.). Upper Saddle River, NJ: PrenticeHall. 2009.

[20] Harry, B. K. "Moral Education: Relevance, Goals and Strategies". Journal of Moral Education, 6(2), 121-130. 1977. https://doi.org/10.1080/0305724770060205

[21] Harry, C. B. "Perspectives: A Challenging Patriotism, Change". The Magazine of Higher Learning, 44(4), 22-26. 2012. https://doi.org/10.1080/00091383.2012.691859

[22] Hong, E. "Liberal education reconsidered: cultivating humanity in the knowledge society". Asia Pacific Education Review, 15, 512. 2014.https://doi.org/10.1007/s12564-013 $-9291-8$

[23] Hyemin, H., Sung, C. P., Jongsung, K., Changwoo, J., Yutaka, K., and Sora, K. "A quantitative analysis of moral exemplars presented in moral education textbooks in Korea and Japan". Asia Pacific Journal of Education, 38(1), 62-77. 2018. https://doi.org/10.1080/02188791.2018.1423950

[24] Jacomijn, C. K., Doret, J. R., and Siebren, M. "The influence of moral education on the personal worldview of students". Journalof Moral Education, 44(3), 346-363. 2015. https://doi.org/10.1080/03057240.2015.1048790

[25] Jennifer, B. "Fostering moral understanding, moral inquiry $\&$ moral habits through philosophy in schools: a Deweyian analysis of Australia's Ethical Understanding curriculum”. Journal of Curriculum Studies, 52(1), 84-100. 2020. https://doi.org/10.1080/00220272.2019.1650116

[26] Julia, J., Supriatna, E., Isrokatun, I., Aisyah, I., Hakim, A., and Odebode, A. A. "Moral Education (2010-2019): A Bibliometric Study (Part 2)". Universal Journal of Educational Research, 8(6), 2554-2568. 2020. https://doi.org/10.13189/ujer.2020.080639

[27] Koon, L. W., Chi, K. J. L., Kin, S. J. C., and Kerry, J. K. "Constructions of civic education: Hong Kong teachers' perceptions of moral, civic and national education". Compare: A Journal of Comparative and International Education, 47(5), 628-646. 2017. https://doi.org/10.1080/0 3057925.2016 .1262756

[28] Kodelja, Z. "Is Education for Patriotism Morally Required, Permitted or Unacceptable?". Studies in Philosophy and Education, 30, 127-140. 2011. https://doi.org/10.1007/s112 17-011-9233-Z

[29] Krek, J., Hodnik, T., and Vogrinc, J. "The primary school moral education plan in Slovenia ten years after its introduction".

[30] European Journal of Educational Research, 8(4), 1229-1243. 2019. https://doi.org/10.12973/eu-jer.8.4.1229

[31] Laurance, S. "Identity, Citizenship and Moral Education". Educational Philosophy and Theory, 43(5), 484-505. 2011. https://doi.org/10.1111/j.1469-5812.2009.00626.x

[32] Larry, N. "Recovering the role of reasoning in moral education to address inequity and social justice". Journal of Moral Education, 45(3), 291-307. 2016. https://doi.org/10.1080/03057240.2016.1167027

[33] Lawrence. E. G. "Vietnam's Thrust into Globalization: Doi Moi's Long Road". Asian Affairs: An American Review, 33(3), 151-166. 2006. https://doi.org/10.3200/AAFS.33.3.
$151-166$

[34] Linh, P. H. T., and Azar, A. S. "A Comparative Study of the Inclusive Education Policy in Vietnam and Malaysia: Proposed Solutions for Sustainable Development Education in Vietnam". Education Quarterly Reviews, 2(3), 539-550. 2019. https://doi:10.31014/aior.1993.02.03.86

[35] Lo, P., and Welch, N. "The Path from the Village: The Education of Thai Ethnic Students in Vietnam". Australian and International Journal of Rural Education, 29(1), 72-87. 2019. https://journal.spera.asn.au/index.php/AIJRE/article/ view/178

[36] Le, T. H. "Educating some traditional moral values of the family for Vietnamese students today". Journal of Education, 5, 265-268. 2018.

[37] Matthew, C. and David, S. "The poverty of contractarian moral education". Journal of Moral Education, 48(4), 501-514. 2019. https://doi.org/10.1080/03057240.2019.15 76123

[38] Michael, H. "Moral education and the justification of basic moral standards: Replies to Clayton, Stevens and D'Olimpio". Journal of Moral Education, 48(4), 529-539. 2019. https://doi.org/10.1080/03057240.2019.1626704

[39] Nel, N. "Moral Life and Education". Action in Teacher Education, 38(3), 212-216. 2016. https://doi.org/10.1080/0 1626620.2016 .1194783

[40] Nieto, S. "A Lifetime of Language, Literacy, Identity, and Solidarity". Literacy Research: Theory, Method, and Practice, 69(1), 137-153. 2020. https://doi:10.1177/238133 6920937420

[41] Nguyen, H. T. "Exploring the organizational culture of higher education institutions in Vietnam from faculty's perspective - a case study". Journal of International and Comparative Education, 9(2), 59-76. 2020. https://doi:10.1 4425/jice.2020.9.2.0704

[42] Nguyen, T. C. "Educating Vietnamese traditional moral values for today's students". Journal of Education, 1(5), 261-264. 2018

[43] Nguyen, V. H. "Lifestyle of Vietnamese under the effects of globalization at present". Vietnam Journal of Philosophy, 12, 29-34. 2003.

[44] Nguyen, T. T. H. "Globalization and the risk of ethic and lifestyle deterioration to Vietnamese people at present". In: Pham, V. D. (eds) Globalization in AsiaPacific context some philosophy issues. Vietnam: Science and Society Publisher, 306-313. 2007.

[45] Nunnally, J. C., and Bernstein, I. H. "Psychometric theory" (3rd ed.). New York: McGraw-Hill. 1994.

[46] Panos, P. "Moral beauty and education". Journal of Moral Education, 48(4), 395-411. 2019.

[47] https://doi.org/10.1080/03057240.2019.1584554

[48] Phung, V. H. "Public Investment in Education and Training in Vietnam". International Education Studies, 11(7), 106-115. 2018.https://doi.org/10.5539/ies.v11n7p106

[49] Pham, V. T. and Bui, T. N. "Moral Education at Vietnamese Schools in the Present Globalization Trend". American 
Journal of Educational Research, 6(6), 795-803. 2018. https://doi:10.12691/education-6-6-31

[50] Shuyi, C., and Jasmine, B. Y. S. "Rethinking critical patriotism: a case of constructive patriotism in Social Studies teachers in Singapore". Asia Pacific Journal of Education, 37(1), 1-13. 2017. https://doi.org/10.1080/0218 8791.2016 .1142425

[51] Song, S. "Problems and Countermeasures in Moral Education of Counselors in Southwest Petroleum University". Creative Education, 10, 1357-1364. 2019. https://doi:10.4236/ce.2019.107101

[52] Sukowati., Sartono, E. K. E., Jerusalem, M. A., and Rahmawati, P. "The Teachers' Knowledge of the Spirit of Nationality and Its Implementation Strategy: A Study to Improve the Spirit of Nationality". Anatolian Journal of Education, 6(1), 117-130. 2021.https://doi.org/10.29333/aj e.2021.6110a

[53] Susana, F. and Guillermo, E. D. "Moral education as intercultural moral education. Intercultural Education, 29(1), 18-39. https://doi.org/10.1080/14675986.2017.1405214

[54] Siraj, S. , Zakaria, A. , Alias, N. , Dewitt, D. , Kannan, P. \& Ganapathy, J. "Future Projection on Patriotism among School Students Using Delphi Technique". Creative Education, 3, 1053-1059. 2012. https://doi:10.4236/ce.201 2.326158

[55] Sebastian, E. "Kindred Spirits: Learning to Love Nature the Posthuman Way". Journal of Philosophy of Education, 53(3), 503-517. 2019. https://doi.org/10.1111/1467-9752.1 2379

[56] Thao, P. N. "Searching for education for sustainable development in Vietnam". Environmental Education Research, 25(7), 991-1003. 2019. https://doi.org/10.1080/1 3504622.2019 .1569202

[57] Trang, T. T. N. "Bilingual identity of ethnic minority students: insights from Vietnam". International Journal of Bilingual Education and Bilingualism, 24(1), 91-106. 2021. https://doi.org/10.1080/13670050.2018.1445697
[58] Tran, T.A., Tran, T.Q., Tran, N.T. et al. "The role of education in the livelihood of households in the Northwest region, Vietnam".

[59] Educational Research for Policy and Practice, 19, 63-88. 2020. https://doi.org/10.1007/s10671-018-9242-6

[60] Tobias, K. "Moral sciences and the role of education". Journal of Moral Education, 50(1), 77-91. 2021. https://doi.org/10.1080/03057240.2020.1784713

[61] Van, S. H., Minh, H. N. T., Vinh, K. N., Vinh, L. S., Thien, V. G. "Forecasting the Results of Students Attending School in Vietnam by Geographical Area". International Journal of Education and Practice, 7(3), 274-285. 2019. https://doi:10.18488/journal.61.2019.73.274.285

[62] $\mathrm{Vu}, \mathrm{T} . \mathrm{T}$. "Early childhood education in Vietnam, history, and development". International Journal of Child Care and Education Policy, 15(3). 2021. https://doi.org/10.1186/s40 723-020-00080-4

[63] Wang, Z. "Study on countermeasures on moral education through school network". US-China Education Review, 6(1), 44-48. 2009. https://files.eric.ed.gov/fulltext/ED5038 90.pdf

[64] Wang, J. and Jia, S. "The Contemporary Value of Patriotism". Advances in Applied Sociology, 5, 161-166. 2015. https://doi:10.4236/aasoci.2015.55015

[65] Xi, W., and Ting, W. "Discourse on nationalism in China's traditional cultural education: Teachers' perspectives". Educational Philosophy and Theory, 50(12), 1089-1100. 2018. https://doi.org/10.1080/00131857.2018.1434074

[66] Yaacob, A. "Attitudes among Students towards Gender Beliefs and Moral Values at Higher Learning Institutions in Malaysia".

[67] Open Access Library Journal, 2, 1-8. 2015. https://doi:10.4236/oalib.1101133

[68] Zhang, Y. "Analysis and Discussion on Chinese College Students' Moral Characteristics and Its Countermeasures". Open Journal of Social Sciences, 3, 76-80. 2015. https://doi:10.4236/jss.2015.33014 